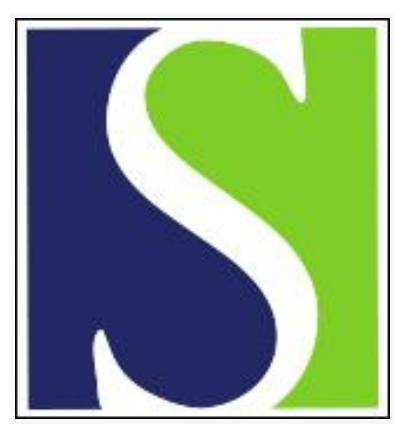

Scand J Work Environ Health 1993;19(5):326-333

https://doi.org/10.5271/sjweh.1467

Issue date: 01 Oct 1993

Risk indicators of ischemic heart disease among male professional drivers in Sweden.

by Hedberg GE, Jacobsson $\mathrm{KA}$, Janlert $\mathrm{U}$, Langendoen $\mathrm{S}$

Affiliation: Division of Applied Work Physiology, National Institute of Occupational Health, Umea, Sweden.

The following article refers to this text: 2015;41(1):54-64

This article in PubMed: www.ncbi.nlm.nih.gov/pubmed/8296181

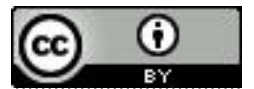




\title{
Risk indicators of ischemic heart disease among male professional drivers in Sweden
}

\author{
by Gudrun E Hedberg, DrMedSc, ${ }^{1}$ Karl A Jacobsson, MD, ${ }^{2}$ Urban Janlert, DrMedSc, ${ }^{3}$ \\ Stina Langendoen, MedTech ${ }^{1}$
}

\begin{abstract}
HEDBERG GE, JACOBSSON KA, JANLERT U, LANGENDOEN S. Risk indicators of ischemic heart disease among male professional drivers in Sweden. Scand J Work Environ Health 1993;19:326-33. Possible risk indicators of ischemic heart disease relevant to the occupation of professional driving were identified in a cohort of 440 professional drivers and 1000 referents from the Swedish counties of Västerbotten and Norrbotten. The subjects were randomly selected. Data on cardiovascular risk indicators were collected from questionnaires, blood pressure measurements, serum lipid levels, height, and weight. The results showed that significantly more drivers than referents were overweight, smokers, and shift workers; were sedentary in their leisure time; and had a work situation characterized by high demands, low decision latitude, and low social support. There were no significant differences concerning blood pressure and serum lipid levels. The odds ratio for having a high score on a cardiovascular risk index was 3.18 (95\% confidence interval $2.41-4.20$ ) for the drivers when they were compared with the referents. When adjusted for age, heredity, shift work, educational level, marital status, and working class, the odds ratio was 2.34 (95\% confidence interval $1.70-3.21$ ).
\end{abstract}

Key terms: bus drivers, job strain, overweight, physical activity, smoking habits, social support, truck drivers, work environment.

Several investigations have indicated that cardiovascular diseases affect professional drivers more often than many other occupational groups. One of the earliest studies in this field was conducted by Morris et al (1). In an investigation of 667 middle-aged busmen (2) a higher incidence of coronary heart disease was found among bus drivers than among bus conductors. A study of the relationship between mortality and occupation in the Nordic countries in the 10-year period 1971-1980 (3) showed increased mortality from cardiovascular diseases among road transport workers in all Nordic countries when they were compared with all economically active men. A Danish study of bus drivers (4) showed that mortality due to coronary heart disease was significantly higher among bus drivers than among a reference group representing employed men in Copenhagen. An investigation into mortality from circulatory diseases, especially ischemic heart disease in a cohort of 1713 Swedish professional drivers (5) showed that the standardized mortality ratio (SMR) for circulatory diseases and ischemic heart disease were significantly higher in a group of professional drivers than in a reference group of Swedish men (SMR 127 and 138, respectively). A Norwegian study of coro-

1 Division of Applied Work Physiology, National Institute of Occupational Health, Umeå, Sweden.

2 Department of Medicine, University of Umeå, Sweden. 3 Department of Social Medicine, Luleå, Sweden.

Reprints requests to: Dr $\mathrm{G}$ Hedberg, National Institute of Occupational Health, PO Box 7654, S-907 13 Umeå, Sweden. nary risk indicators in various occupational groups (6) showed that, among road transport workers, the coronary risk score was high because of the workers' high serum cholesterol levels and because many of the workers smoked. Taxi and bus drivers with a low income and a poor education had a particularly high risk score. In a study of coronary risk indicators by Hartvig \& Midttun (7) bus and truck drivers were compared with industrial workers. The results showed higher mean values for serum cholesterol, serum triglyceride, and blood pressure in the driver group and therefore indicated a markedly higher risk of cardiovascular disease for that group.

The purpose of our investigation was to identify possible risk indicators of ischemic heart disease relevant to the occupation of professional drivers so that a preventive strategy can be devised against the development of ischemic heart disease in this occupational group.

\section{Subjects and methods}

\section{Study base}

The driver group consisted of male drivers from the Swedish counties of Västerbotten and Norrbotten. In the two counties there were altogether 903 bus drivers and 2746 truck drivers. Of the drivers, $12 \%$ was randomly selected from lists of members of the national unions to which drivers belong. To be selected, the driver had to have been a member of the union for at least three years. The limit of three years was chosen for the study to exclude drivers with only 
short work experiences. The research group consisted of 110 male bus drivers and 330 male truck drivers between 25 and 64 years of age.

The reference group included all men in the MONICA (multinational monitoring of determinants and trends in cardiovascular diseases) study of the World Health Organization (WHO) in the northern Swedish MONICA center, which covered the counties of Västerbotten and Norrbotten. In the MONICA study (8) determinants and trends in cardiovascular disease are being monitored during a 10 -year period in 40 centers in 27 countries. The study is exploring whether the differences in cardiovascular risk factor profiles in different geographic settings are related to the incidence of cardiovascular diseases and case fatality rates. The reference group consisted of 1000 male subjects from the counties of Västerbotten and Norrbotten. Stratified randomization from the total population between 25 and 64 years of age was used to select these subjects. The stratification included the following age groups: $25-34,35-44,45-54$ and 55-64 years. In each stratum 250 men were randomly selected from continuously updated population registers.

The mean age of the drivers was 43.8 (95\% CI $42.8-44.8)$ years. In figure 1 the age distribution of the drivers is shown in relation to the age distribution of the male population in the counties of Västerbotten and Norrbotten. The proportion of drivers was lower chiefly in the age group 60-64 years. Within the driver group $78 \%$ were married or cohabiting, while the figure was $82 \%$ for the reference group.

Regarding educational background $80 \%$ of the drivers had only completed compulsory schooling (seven years for the oldest and nine years for the youngest groups), 19\% had attended senior high school, and $1 \%$ had attended a university. For the reference group the corresponding figures were 60 , 28 , and $12 \%$, respectively. The difference between the driver and reference groups was significant.
Seventy-five percent of the drivers and $46 \%$ of the referents belonged to the working class. Fourteen percent of the drivers and $10 \%$ of the reference group ran their own business. The difference in the distribution according social class was significant.

For all of the drivers the mean number of years as a professional driver was $18.2(95 \%$ CI $17.0-$ $19.4)$. Significantly more drivers $(63 \%)$ than referents $(32 \%)$ worked shifts or had variable workhours.

\section{Study design}

The subjects were invited by mail to participate in the investigation, which consisted of the following two parts: (i) to answer two questionnaires at home (questionnaires 1 and 2) and (ii) to attend a screening in which measurements were taken and an additional questionnaire (number 3) was answered. If the subject did not keep his first appointment, he was given another by mail or by phone. Since the investigation was coordinated with the WHO MONICA study (8), the same procedure was used as in that investigation. Two teams, each consisting of two nurses and two medical technicians, performed the screenings, carried out between January and April 1990 in the counties of Västerbotten and Norrbotten.

\section{Questionnaires and measurements}

Questionnaire 1 comprised items regarding possible medical history of cardiovascular disease, smoking habits, physical activity during leisure time and work, eating and alcohol habits, and work conditions. Questionnaire 2 included items concerning occupation and tasks. Questionnaire 3 dealt with social support during leisure time. When items of information were missing, the questionnaires were completed by the respondent on the occasion of the examination.

Blood pressure levels were measured twice by the random zero method (9) in a sitting position after 5 min of rest. The mean value of two measurements
Figure 1. Numbers of professional drivers per 1000 men in the male population of the counties of Västerbotten and Norrbotten.

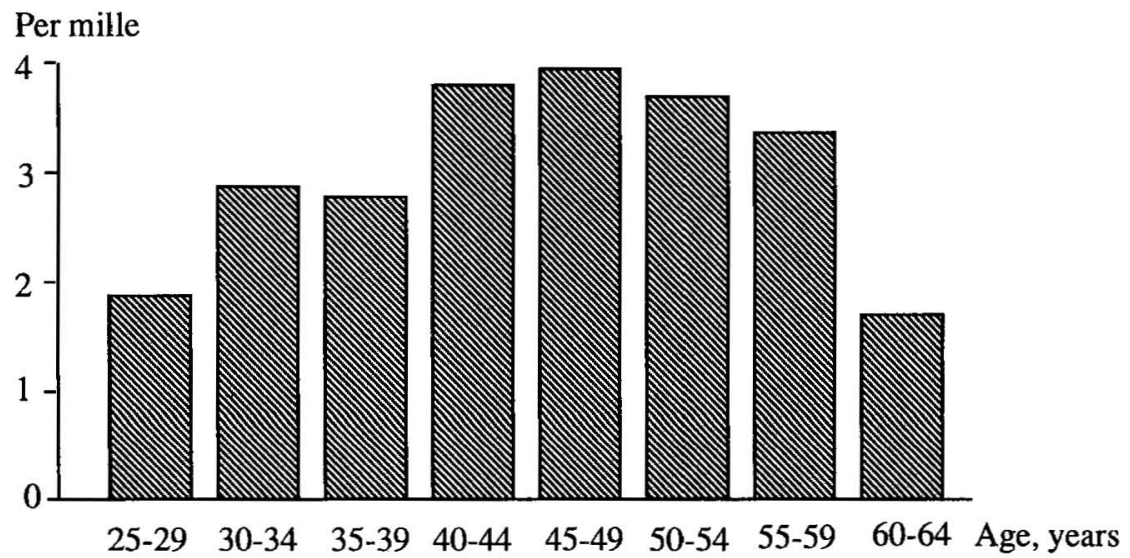


was calculated. Before the screening started, training sessions with the two teams were conducted to ensure conformity.

Serum samples were obtained for the determination of total cholesterol and high-density lipoprotein (HDL) after fasting for a minimum of $4 \mathrm{~h}$. Serum samples were also obtained for the determination of triglyceride after fasting for a minimum of $12 \mathrm{~h}$. Because of the long period of fasting, triglyceride was measured for only $65 \%$ of the subjects, randomly selected. Total cholesterol was measured by the enzymatic method and HDL cholesterol by phosphotungstate- $\mathrm{MG}^{++}$precipitation with the use of commercial kits (Boehringer Mannheim).

Weight was measured with an electronic balance, which was calibrated daily. During the weighing, the subjects wore only a shirt and trousers and no shoes; no corrections were made. Height was also measured without shoes. Body mass index was calculated as weight $(\mathrm{kg}) \cdot$ length $^{-2}(\mathrm{~m})$.

\section{Analysis of nonrespondents}

A total of $89 \%$ of all drivers answered the postal questionnaires. The screening investigation was attended by $85 \%$. Four percent could not participate in the screening, mainly due to their workhours. Most of the nonrespondents in the screening belonged to the 25- to 34-year age group (16\%). The dropout was $7 \%$ in the 35 - to 44 -year age group, $14 \%$ in the 45 to 54 -year age group, and $13 \%$ in the 55 - to 64 -year age group.

Seventy-eight percent of the reference group answered the questionnaires and participated in the screening. Most of the nonrespondents were found in the youngest age group (38\%). In the 35- to 44year age group the dropout rate was $21 \%$, whereas in the 45- to 54-year and 55- to 64-year age groups it was 21 and $20 \%$, respectively.

\section{Data processing and statistics}

We used the Swedish sociocconomic classification (10) in determining the distribution according to social class.

A measure of fat consumption was constructed by multiplying the daily number of glasses of milk by their average fat content.

The responses to the five questions dealing with social support at work were used to calculate an index for this variable (11). The higher the index, the better the social support at work.

An index concerning the quality and quantity of social support during leisure time was calculated according to a model by Henderson et al (11) from the responses to the 13 questions dealing with this variable. The higher the index, the better the social support.

Ten questions dealt with the psychosocial work environment according to a model by Karasek \& Theorell (12). The model describes the job situation of a worker by means of the demands made and the decision latitude given during work. From the answers to these questions indices were calculated with which to group the subjects into the following four different job situations: active (high demands and high decision latitude), low strain (low demands and high decision latitude), high strain (high demands and low decision latitude), and passive (low demands and low decision latitude).

The significance of the difference between two distributions was tested with the chi-square test or the analysis of variance for continuous variables, and for the difference between the mean values the t-test was used. The $5 \%$ level was chosen as the critical level of significance. The $95 \%$ confidence intervals (95\% CI) have also been reported. To eliminate differences between the driver and reference groups due to different age structures within the groups, we standardized the data for age with the age structure of the drivers as reference.

A cardiovascular risk index was calculated to sum up the different risk indicators (risk indicators concerning medical aspects, life-style, and job situation). The score +1 was given to each of the following five risk indicators: hypertension [medical treatment or diastolic blood pressure $\geq 90 \mathrm{~mm} \mathrm{Hg} \mathrm{(} \geq 11.97 \mathrm{kPa})$ ], high fat consumption (over median), daily tobacco use, low leisure-time physical activity, and finally a job situation characterized by high demands and low decision latitude (high strain) (11). The score could thus vary between 0 and 5 . The risk score was then dichotomized so that those with a risk score above the median had a score of 1 and all others had a score of 0 . The odds ratio (OR) was calculated. Adjustment for potential confounders was made with the logistic regression. Heredity (a close relative having died of cardiovascular disease), marital status (single or widow/widower), age ( $\geq 45$ years old), shift work, educational level (only compulsory schooling), and working class membership were regarded as confounders.

The study was approved by the regional Ethics Research Committee of the University of Umeå. The data processing procedures were approved by the National Computer Data Inspection Board.

\section{Results}

\section{Risk indicators}

The prevalence of ischemic heart disease, stroke, and diabetes did not differ significantly between the two groups. Significantly more drivers than referents had close relatives who had died of cardiac infarction before the age of 65 years. Concerning mortality from stroke, there was no significant difference between the two groups.

For the drivers the mean value was $130 \mathrm{~mm} \mathrm{Hg}$ $(17 \mathrm{kPa})(95 \%$ CI $128-132)$ for systolic blood pressure and $83 \mathrm{~mm} \mathrm{Hg}(95 \% \mathrm{CI}=82-84)$ for diastolic 
blood pressure. There were no significant differences between the drivers and referents regarding the mean values of blood pressure or regarding treatment for hypertension.

The drivers had a mean value of $6.32(95 \% \mathrm{CI}$ $6.19-6.45) \mathrm{mmol} \cdot \mathrm{I}^{-1}$ for total cholesterol in serum, and the corresponding value for the referents was $6.30(95 \% \mathrm{Cl} 6.22-6.39) \mathrm{mmol} \cdot \mathrm{l}^{-1}$. The mean values increased with age up to 54 years of age. The mean value for the drivers decreased in the 55- to 64-year age group (figure 2).

The mean value for HDL cholesterol was 1.26 (95\% CI 1.23-1.30) $\mathrm{mmol} \cdot \mathrm{l}^{-1}$ for the drivers and $1.28(95 \%$ CI $1.25-1.30) \mathrm{mmol} \cdot \mathrm{l}^{-1}$ for the reference group. The difference was not significant.

Triglyceride had a mean value of $1.85(95 \% \mathrm{CI}$ $1.51-2.19) \mathrm{mmol} \cdot \mathrm{l}^{-1}$ for the drivers and $1.63(95 \%$ $\mathrm{CI}=1.55-1.71) \mathrm{mmol} \cdot 1^{-1}$ for the reference group. The difference was not significant.

A comparison between the drivers and the referents showed a significantly higher share of smokers among the drivers (table 1). There was no significant difference between the two groups with respect to the use of snuff.

Table 2 shows the self-reported physical activity at work. More drivers than referents had sedentary and heavy work. The opposite was true for light and some flexible work. The difference in the distribution of the responses was significant.

The frequency of drivers regularly engaging in moderate physical activity during leisure time increased with age. There was a significant difference between the drivers and the referents regarding leisure-time physical activity. More men in the reference group had a higher degree of physical activity (table 3).

\section{Serum total cholesterol} $\mathrm{mmol} \cdot \mathrm{r}^{-1}$

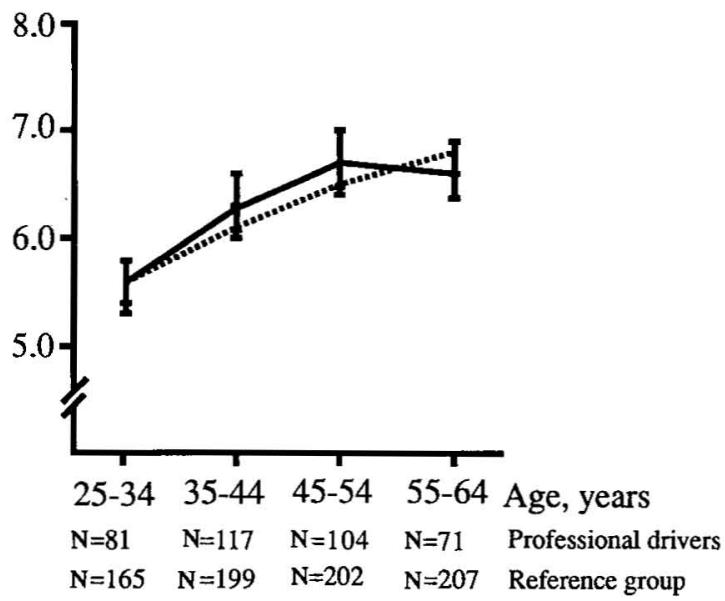

Figure 2. Mean value and $95 \%$ confidence interval for serum total cholesterol in the professional drivers (solid line) and referents (broken line) in relation to the age groups.
The drivers averaged 6.3 (95\% CI 5.9-6.6) cups of coffee per day, and the referents had 5.5 (95\% CI $5.3-5.8$ ) cups. The difference was significant. The drivers also consumed a significantly higher proportion of milk fat per day [mean $7.69(95 \%$ CI $7.0-$ 8.4) g] than the referents [mean $5.73(95 \%$ CI 5.3$6.2) \mathrm{g}]$. The remaining dietary data will be presented in a special article. There were no differences between the drivers and the referents concerning alcohol consumption.

The mean value of the body mass index was 26.3 (95\% CI 26.0-26.7) for the drivers and 25.9 (95\% $\mathrm{CI}=25.6-26.1)$ for the reference group. The difference between the two groups was significant. For the drivers the mean body mass index increased with advancing age up to $55-64$ years of age (figure 3).

Table 1. Smoking among the professional drivers and referents.

\begin{tabular}{lcc}
\hline & $\begin{array}{c}\text { Drivers } \\
(\mathrm{N}=392) \\
(\%)\end{array}$ & $\begin{array}{c}\text { Referents } \\
(\mathrm{N}=776) \\
(\%)\end{array}$ \\
\cline { 2 - 3 } & 31 & 23 \\
Regular smokers & 8 & 8 \\
Occasional smokers & 61 & 69 \\
Nonsmokers & 100 & 100 \\
\hline Total & $\mathrm{X}^{2}=9.8, \mathrm{df}=2 ; \mathrm{P}=0.01$ \\
\hline
\end{tabular}

Table 2. Levels of occupational physical activity reported by the professional drivers and referents.

\begin{tabular}{lcc}
\hline $\begin{array}{l}\text { Level of physical } \\
\text { activity }\end{array}$ & $\begin{array}{c}\text { Drivers } \\
(\mathrm{N}=368) \\
(\%)\end{array}$ & $\begin{array}{c}\text { Referents } \\
(\mathrm{N}=771) \\
(\%)\end{array}$ \\
\hline $\begin{array}{l}\text { Sedentary } \\
\text { Light and some flexible }\end{array}$ & 30 & 18 \\
Moderate-to-heavy & 22 & 39 \\
Heavy & 30 & 30 \\
\hline Total & 18 & 13 \\
\hline & 100 & 100 \\
& $X^{2}=40.62 ; \mathrm{df}=3 ; \mathrm{P}<0.001$ \\
\hline
\end{tabular}

Table 3. Levels of leisure-time physical activity among the professional drivers and referents.

\begin{tabular}{|c|c|c|}
\hline $\begin{array}{l}\text { Level of physical } \\
\text { activity }\end{array}$ & $\begin{array}{c}\text { Drivers } \\
(\mathrm{N}=390) \\
(\%)\end{array}$ & $\begin{array}{c}\text { Referents } \\
(\mathrm{N}=771) \\
(\%)\end{array}$ \\
\hline Very low or low & 33 & 17 \\
\hline Light (twice a week) & 47 & 48 \\
\hline High ( $1-3 \mathrm{~h}$ a week) & 15 & 30 \\
\hline $\begin{array}{l}\text { Very high (several times } \\
\text { a week) }\end{array}$ & 4 & 5 \\
\hline Total & $\begin{array}{c}100 \\
X^{2}=46.4\end{array}$ & $\begin{array}{c}100 \\
P<0.001\end{array}$ \\
\hline
\end{tabular}


The questions concerning social support at work referred to the current job. The results of the calculated index showed that the drivers had significant-

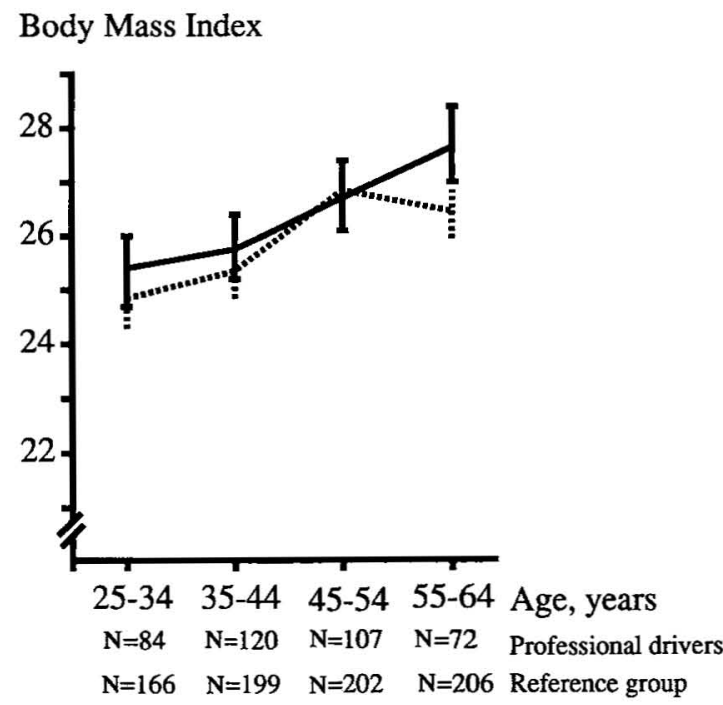

Figure 3. Mean value and $95 \%$ confidence interval for the body mass index [weight $(\mathrm{kg}) \cdot$ length $\left.{ }^{-2}(\mathrm{~m})\right]$ of the professional drivers (solid line) and referents (broken line) in relation to the age groups. ly less social support at work than the referents (table 4). The results of the calculated index concerning social support during leisure time showed a significant difference between the drivers and the referents as regards quantitative but not qualitative social support (table 4).

Significantly more drivers $(15 \%)$ than referents (7\%) reported that they lifted, carried, or dragged heavy items several times an hour. Significantly more drivers than referents also thought that the job involved physical strain and mental stress.

The results of the analysis of the relationship between the psychological demands and decision latitude in current job showed that more professional drivers $(40 \%)$ than referents $(18 \%)$ had a work situation characterized by high strain (high demands and low decision latitude) (figure 4). The difference between the distribution of the drivers and the referents was significant for the four job situations.

\section{Cardiovascular risk index}

Table 5 shows the occurrence of the risk indicators included in the cardiovascular risk index. The odds ratio for having a high score on the cardiovascular risk index was 3.18 (95\% CI $2.41-4.20)$ for the drivers in comparison with the referents. When adjusted for age, heredity, shift work, educational lev-

Table 4. Means and $95 \%$ confidence intervals $(95 \% \mathrm{Cl})$ of the indices concerning social support at work and quantitative and qualitative social support during leisure time for the professional drivers and the referents.

\begin{tabular}{|c|c|c|c|c|c|c|}
\hline \multirow{3}{*}{ Group } & \multicolumn{6}{|c|}{ Index } \\
\hline & \multicolumn{2}{|c|}{ Social support at work } & \multicolumn{2}{|c|}{$\begin{array}{l}\text { Quantitative support } \\
\text { during leisure time }\end{array}$} & \multicolumn{2}{|c|}{$\begin{array}{l}\text { Qualitative support } \\
\text { during leisure time }\end{array}$} \\
\hline & Mean & $95 \% \mathrm{Cl}$ & Mean & $95 \% \mathrm{Cl}$ & Mean & $95 \% \mathrm{Cl}$ \\
\hline \multirow[t]{2}{*}{$\begin{array}{l}\text { Drivers } \\
\text { Referents }\end{array}$} & $\begin{array}{l}13.6 \\
15.5\end{array}$ & $\begin{array}{l}13.2-14.0 \\
15.3-15.7\end{array}$ & $\begin{array}{l}12.7 \\
12.4\end{array}$ & $\begin{array}{l}12.5-12.9 \\
12.3-12.6\end{array}$ & $\begin{array}{l}10.9 \\
10.7\end{array}$ & $\begin{array}{l}10.9-11.1 \\
10.0-10.9\end{array}$ \\
\hline & \multicolumn{2}{|c|}{$F=85.6, \quad P<0.001$} & \multicolumn{2}{|c|}{$F=4.46, \quad P=0.04$} & \multicolumn{2}{|c|}{$F=0.82, \quad P=0.37$} \\
\hline
\end{tabular}

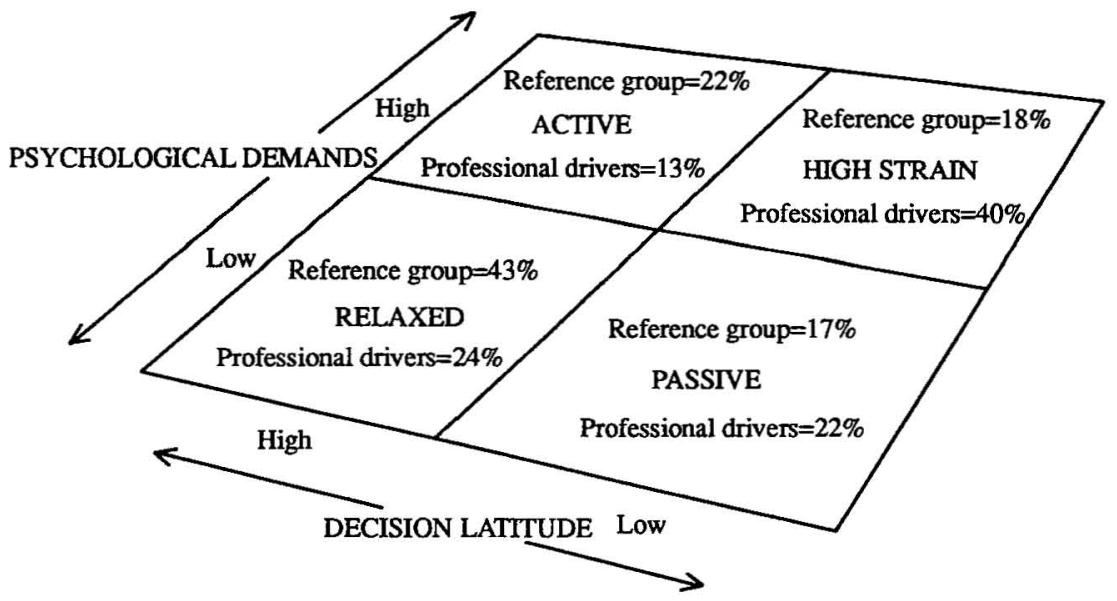

Figure 4. Distribution of the professional drivers $(\mathrm{N}=352)$ and the referents $(N=650)$ into four different job situations according to a model by Karasek et al (26). 
Table 5. Occurrence of the components of the risk index among the professional drivers and referents.

\begin{tabular}{lccc}
\hline Risk indicator & $\begin{array}{c}\text { Drivers } \\
(\%)\end{array}$ & $\begin{array}{c}\text { Refer- } \\
\text { ents } \\
(\%)\end{array}$ & P-value \\
\hline $\begin{array}{l}\text { Hypertension } \\
\begin{array}{l}\text { High fat consumption } \\
\text { (over median) }\end{array}\end{array}$ & 33 & 35 & NS \\
$\begin{array}{l}\text { Daily tobacco consumption } \\
\text { Low leisure-time physical }\end{array}$ & 49 & 50 & $<0.001$ \\
$\begin{array}{l}\text { activity } \\
\text { Job situation described }\end{array}$ & 33 & 17 & $<0.001$ \\
as high strain & 40 & 18 & $<0.001$ \\
\hline
\end{tabular}

el, marital status, and working class membership, the odds ratio was 2.34 (95\% CI 1.70-3.20) (table 6).

\section{Discussion}

The drivers represented professional drivers who had been members of the national unions for at least three years. There may have been a few drivers who were not members of any union. However, it seems plausible to assume that in such cases these men work as drivers only on a casual basis. Since the selection was carried out according to the criterion of three years of experience, determined from union membership, the number of missing drivers was probably low. Some of the drivers own of their own trucks as one-man firms. These drivers are members of the union of haulage contractors, which was a part of the basis for the selection.

The two groups of subjects were obtained by random selection. Both groups were investigated with the same methods and by the same research team. The results obtained therefore cannot be explained by differences in the methods of selection or measurement. There were few nonrespondents. There were also only small differences in the numbers of nonrespondents among bus and truck drivers and among the drivers from the two counties and among the age groups. Therefore there is no reason to believe that nonrespondents have affected the results in any particular direction.

The proportion of drivers in relation to the male population decreases chiefly in the age group 6064 years (figure 1). This decrease could be an effect of a health-based dropout from the job of professional driver ("healthy worker effect") as has been shown in an earlier study of health among professional drivers (13). In a study of factors influencing turnover among Swedish professional drivers (14), older drivers often gave health factors such as cardiovascular diseases and musculoskeletal complaints as reasons for leaving the trade. In this study the reference group was a sample from the total population and thus included both actively working men and men out of
Table 6. Odds ratio (OR) and $95 \%$ confidence interval $(95 \%$ Cl) for the professional drivers' having a high score on a cardiovascular risk index as compared with the referents.

\begin{tabular}{lcc}
\hline & OR & $95 \% \mathrm{Cl}$ \\
\cline { 2 - 3 } & 3.18 & $2.41-4.20$ \\
No control for confounders & & \\
Control for confounders & 3.18 & $2.41-4.20$ \\
$\quad$ Heredity & 3.18 & $2.41-4.21$ \\
Marital status & 3.13 & $2.37-4.14$ \\
Age & 3.03 & $2.27-4.06$ \\
Shift work & 3.01 & $2.27-4.06$ \\
Educational level & 2.78 & $2.07-3.72$ \\
Working class membership & 2.34 & $1.70-3.21$ \\
All above confounders &
\end{tabular}

work. Therefore the figures given may be an underestimation of the risk indicators in a population consisting of only actively working men.

\section{Risk indicators}

The results of this study showed that many professional drivers did sedentary or heavy work and were not physically active during their leisure time. Research results are contradictory concerning the effect of physical activity at work on the prevention of cardiovascular diseases. The study by Morris \& Crawford (15) pointed out that a high level of physical activity at work is a factor which prevents cardiovascular disease. A classic study of the incidence of ischemic heart disease in male bus drivers and conductors by Morris et al (2) showed a higher incidence among bus drivers. The authors thought that this was partly a consequence of less physical activity at work among the drivers.

A study by Holme et al (16) has shown an increase in mortality from coronary heart disease with increasing physical activity during work. On the other hand the coronary heart disease mortality decreased as the degree of leisure-time physical activity increased. One reason for this difference may be the type of physical activity involved. Leisure-time physical activity often includes aerobic training, while physical activity at work - especially the work of truck drivers $(17,18)$ - can involve much heavy lifting and dragging combined with periods of sedentary work. In this study about one-third of the truck drivers reported that they lifted, carried, or dragged heavy objects once or several times an hour. Heavy lifts and heavy dragging work involve both static and dynamic elements, for example, when drivers carry or drag weights. A significant increase in both systolic and diastolic blood pressure can be related to static muscle contractions, especially if the contractions are forced to exhaustion. If static work is combined with dynamic work, the increase in the blood pressure will occur from a higher level (19). According to Folkow (20) frequently repeated pressor bouts every day over a long period can give rise to cardiovas- 
cular structural adaptations that can lead to permanent high blood pressure. However, in this study, there was no difference between the drivers and the referents concerning blood pressure.

Many drivers were overweight. Investigations have shown that obesity can be related to the development of cardiovascular disease either as a precursor to the development of other coronary risk indicators or as a risk factor in itself $(21,22)$. The excess proportion of those overweight among the drivers could have been a consequence of their eating habits and their low level of physical activity both at work and during their leisure time. Many drivers (63\%) worked shifts or had variable workhours and were often forced to eat out.

Several investigations have shown that a poor social network and a lack of social support increases the risk of cardiovascular disease $(23,24)$. A 10year follow-up of middle-aged men showed that social isolation is as important a risk indicator as traditional clinical risk indicators (25). Ischemic electrocardiographic changes were four times more frequent among men with poor emotional support than among men with good emotional support. This relationship was independent of other risk indicators and earlier prevalence of cardiovascular disease. Among the drivers in our study the social support at work was significantly lower than in the reference group. On the other hand there were only small differences between the groups concerning social support during leisure time. In this case the quantitative support, which is of less importance for cardiovascular diseases, was somewhat better in the driver group.

In this investigation the work of many of the drivers was characterized by a combination of high demands and low decision latitude (high strain). According to a model by Karasek \& Theorell (12) such a work situation leads to a higher risk of coronary heart disease. In an evaluation of the model in a study on 1461 Swedish men, it was shown that symptoms of and mortality from coronary heart disease were more common among the men who had earlier reported that their work was characterized by high strain (26). The association existed after a check for age, education, smoking, and overweight.

Significantly more drivers than referents worked shifts or had variable workhours. According to Pettersson (27) about $27 \%$ of the labor force in Sweden works shifts or has variable workhours. In this investigation $63 \%$ of the drivers had such workhours. Alfredsson et al (28) have shown that shift work and monotony were associated with an excess risk of myocardial infarction, especially in combination with work characterized by low decision latitude or few possibilities for promotion.

Significantly more drivers than referents thought that their job involved mental stress. For bus drivcrs the combination of busy traffic, a tight schedule, and impatient passengers can cause stress at work.
In an investigation among urban bus drivers (29) high work load (driving in heavy traffic) was significantly associated with the occurrence of myocardial infarction. The work of truck drivers also involves mental stress, especially for tanker truck drivers (18) and truck drivers engaged in the distribution of goods (17). The motoring in itself can involve mental stress. Bellet et al (30) found a significant increase in the excretion of catecholamines and 11-hydrocorticosteroid in both normal subjects and patients with coronary heart disease when driving. According to the authors these results suggest that automobile driving represents a mental stress. It is also known that car driving can increase the heart rate considerably and cause electrocardiographic changes (31). Our study focused on a rural and smaller city population. In a Danish study (29) the results showed that urban bus drivers with routes in the center of town have a higher risk of developing ischemic heart disease than their colleagues who have routes in the suburbs. It is possible that the findings of our study would have been clearer in a population representing large cities.

This investigation and an earlier study of Swedish professional drivers (14) have shown that many professional drivers have a low level of education. In a study by Holme et al (32) the lowest social class exhibited a much higher total mortality than the other classes. This difference was pronounced for, among others, coronary heart disease. A Swedish study (33) also showed that social class, defined by occupation, was clearly related to the incidence of coronary heart disease. According to Marmot \& Theorell (34) part of the association between social class and cardiovascular diseases may be due to differences in psychosocial work conditions. These conditions can affect risk through either neuroendocrine mechanisms or life-style. The occupation of professional driving can lead to poor eating and smoking habits and a low level of physical activity during leisure time.

\section{Cardiovascular risk index}

The cardiovascular risk index showed a significantly higher value for the drivers than for the referents. Of the different variables controlled for in the estimation of the odds ratio for having a high cardiovascular risk index, working class membership was the one which affected the odds ratio the most. Educational level and shift work also had a substantial influence on the odds ratio, while heredity, marital status, and age had a minor effect. When all of these potential confounders were taken into account, the odds ratio was reduced from 3.18 to 2.34 , but it was still significantly high. Thus there seems to be factors other than age, heredity, marital status, shift work, educational level, and working class membership that account for the elevated risk among drivers. 


\section{Acknowledgments}

This study was supported by the Swedish Work Environment Fund (88-1161, 90 - 0077) and the Medical Faculty of the University of Umeå. The study was carried out in collaboration with the WHO MONICA study.

The authors would like to thank Professor PO Wester, Dr F Huhtasaari, and Dr K Asplund for giving us the opportunity to coordinate the two studies.

\section{References}

1. Morris JN, Heady JA, Raffle PAB, Roberts CG, Parks JW. Coronary heart-disease and physical activity of work. Lancet 1953;2:1053-111.

2. Morris JN, Kagan A, Pattison DC, Gardner MJ, Raffle PAB. Incidence and prediction of ischaemic heartdisease in London busmen. Lancet 1966;2:553 - 9.

3. Danmarks statistiks trykkeri. Statistical reports of the Nordic countries: occupational mortality in the Nordic countries 1971-1980. Copenhagen: Danmarks statistiks trykkeri, 1988:29.

4. Netterstrøm B, Laursen P. Incidence and prevalence of ischaemic heart disease among urban busdrivers in Copenhagen. Scand J Soc Med 1981;9:75-9.

5. Hedberg $\mathrm{G}$, Jacobsson KA, Langendoen $\mathrm{S}$, Nyström L. Mortality in circulatory diseases, especially ischaemic heart disease, among Swedish professional drivers. J Human Ergol 1991;20:3-7.

6. Holme I, Helgeland A, Hjermann I, Leren P, LundLarsen PG. Coronary risk factors in various occupational groups: the Oslo Study. Br J Prev Soc Med 1977;9:96-100.

7. Hartwig P, Midttun O. Coronary heart disease risk factors in bus and truck drivers: a controlled cohort study. Int Arch Occup Environ Health 1983;52:353 - 60.

8. Huthasaari F, Asplund K, Wester PO. Cardiovascular risk factors in the Northern Sweden MONICA study. Acta Med Scand 1988;224:99-108.

9. Wright BM, Dore CF. A random-zero sphygmomanometer. Lancet 1970;1:337-8.

10. Statistiska centralbyrån (SCB). Meddelanden i samordningsfrågor [Reports on statistical coordination]. In: SCB. Yrkesklassificeringar i FoB 85 enligt Nordisk yrkesklassificering (NYK) och Socioekonomisk indelning (SEI). Alfabetisk version [Occupations in population and housing census 1985 according to Nordic standard occupational classification and Swedish socioeconomic classification. Alphabetical version]. Stockholm: SCB, 1989:5.

11. Henderson S, Duncan-Jones P, Byrne DG, Scott R. Measuring social relationships: the interview schedule for social interaction. Psychol Med 1980;10:72334.

12. Karasek R, Theorell T. Healthy work: stress, productivity and the reconstruction of working life. New York, NY: Basic Books, 1990.

13. Hedberg G, Lipping H. Yrkesförares hälsotillstånd. En enkätstudie [The state of health of professional drivers: a questionnaire study]. Stockholm: Transporthälsan, 1981. (Rapport 1981:4.) (English abstract.)

14. Hedberg $G$, Langendoen $S$. Factors influencing the turnover of Swedish professional drivers. Scand J Soc Med 1989;17:231-7.

15. Morris JN, Crawford M. Coronary heart disease and physical activity of work. Br Med J 1958;1485-96.

16. Holme I, Helgeland A, Hjermann I, Leren P, Lund-
Larsen PG. Physical activity at work and at leisure in relation to coronary risk factors and social class: a 4year mortality follow-up: the Oslo study. Acta Med Scand 1981;209:277-83.

17. Hedberg G. Physical strain in Swedish lorry drivers engaged in the distribution of goods. J Human Ergol $1985 ; 14: 33-40$.

18. Hedberg G, Niemi K. Physical and muscular strain in Swedish tanker truck drivers. Ergonomics 1986;29: $817-26$.

19. Gamberale F, Hansson JE, Jonsson B, Kilbom A, Ljungberg AS. Människans tolerans för lyft- och bärarbete [Criteria in the assessment of manual materials handling]. Stockholm: Arbetarskyddsverket, 1981. (Arbete och Hälsa 1981;6.) (English abstract.)

20. Folkow AB. Physiological aspects of primary hypertension. Physiol Rev 1982;62:347-504.

21. Hubert HB. The nature of the relationship between obesity and cardiovascular disease. Int $\mathrm{J}$ Cardiol 1984;6:268-74.

22. Manson J, Stampfer M, Hennekens C, Willett W. Body weight and longevity: a reassessment. JAMA 1987; 257:353-8.

23. Undén AL. Social support and health: methodology, relationship to work environment and to ischaemic heart disease. Stockholm: National Institute for Psychosocial Factors and Health, 1991.

24. Östergren PO. Psychosocial resources and health: with special reference to social network, social support and cardiovascular disease. Malmö: Department of Community Health Sciences, 1991.

25. Orth-Gomér K, Unden AL, Edwards ME. Social isolation and mortality in ischemic heart disease. Acta Med Scand 1988;224:205-15.

26. Karasek R, Baker D, Marxer F, Ahlbom A, Theorell T. Job decision latitude, job demands and cardiovascular disease: a prospective study of Swedish men. Am J Public Health 1981;71:694-705.

27. Pettersson LO. Hushållens arbetstider [The working hours of the households]. Stockholm: Arbetsmarknadsdepartementet, 1989:5-110. (Arbetstid och välfärd; Bilagedel A, SOU, 1989;53.)

28. Alfredsson L, Karasek R, Theorell T. Myocardical infarction risk and psychosocial work environment: an analysis of the male Swedish working force. Soc Sci Med 1982;16:463-7.

29. Netterstrøm B, Juel K. Impact of work-related and psychosocial factors on the development of ischemic heart disease among urban bus drivers in Denmark. Scand J Environ Health 1988;14:231-8.

30. Bellet S, Roman L, Kostis J. The effect of automobile driving on catecholamine and adrenocortical excretion. Am J Cardiol 1969;25:365-8.

31. Taggart P, Gibbons D, Somerville W. Some effects of motorcar driving on the normal and abnormal heart. Br Med J 1969;4:130—4.

32. Holme I, Helgeland A, Hjermann I, Leren P, LundLarsen PG. Four-year mortality by some socioeconomic indicators: the Oslo Study. J Epidemiol Community Health 1980;34:48-52.

33. Rosengren A, Wedel $\mathrm{H}$, Wilhelmsen L. Coronary heart disease and mortality in middle aged men from different occupational classes in Sweden. $\mathrm{Br}$ Med J 1988;297:14971500.

34. Marmot M, Theorell T. Social class and cardiovascular disease: the contribution of work. Int J Health Serv 1988;18:659-74.

Received for publication: 24 March 1993 